\title{
After Fukushima, Taiwan revisits issue of nuclear risk
}

\section{Tanguy LePesant}

Translator. N. Jayaram

\section{(e) OpenEdition \\ Journals}

\section{Electronic version}

URL: http://journals.openedition.org/chinaperspectives/5572

DOI: 10.4000/chinaperspectives.5572

ISSN: 1996-4617

Publisher

Centre d'étude français sur la Chine contemporaine

\section{Printed version}

Date of publication: 30 July 2011

Number of pages: 62-63

ISSN: 2070-3449

\section{Electronic reference}

Tanguy LePesant, « After Fukushima, Taiwan revisits issue of nuclear risk », China Perspectives [Online] 2011/2 | 2011, Online since 30 June 2014, connection on 15 September 2020. URL : http:// journals.openedition.org/chinaperspectives/5572

(c) All rights reserved 
This section, prepared by the Asia Centre (www.centreasia.org), draws mainly on the press in chinese, aiming to reflect the point of view of the People's Republic of China on

\section{After Fukushima, Taiwan revisits issue of nuclear risk}

\section{Analysis by Tanguy Le Pesant based on:}

- Zhang Zuo-jin, "No nuclear energy without a price," Yuanjian zazhi (Global Views Monthly), April 2011, p. 26.

- Editorial, "Civilian nuclear policy needs immediate review and correction," Ziyou shibao (Liberty Times), 26 March 2011, p. A2.

- Focus, "Review of security in the nuclear energy sector," Yushan zhoubao (Formosa Weekly), 23-30 March 2011, pp. 4-16.

- Tian Zhe-rong, "If Taiwan faced a nuclear catastrophe," Jingdian zazhi (Rhythms Monthly), no.153, April 2011, pp. 60-71.

$\int_{\text {the }}^{a}$ apan's failure to prevent a major nuclear catastrophe at Fukushima, along with the fact that Taiwanese nuclear stations face a similar earthquake risk, have revived debate on the use of nuclear power on the island. As of now, Taiwan has three nuclear plants with a total of six reactors commissioned between 1978 and 1985. They are managed by the public enterprise Taipower (台灣電力公司 - Taiwan dianli gongsi) under the overall direction of the Ministry of Economic Affairs. In 2010, the nuclear sector represented 12.6 percent of installed capacity and 19.3 percent of electricity generated in Taiwan, according to Taipower. A fourth station with two reactors will go into service late next year.

Zhang Zuo-jin says Fukushima reminded the Taiwanese that recourse to nuclear power is a choice that carries a price for society (沒有白吃的午餐 - meiyou baichi de wucan), but is at pains to explain that abandoning nuclear energy carries economic costs. Zhang rejects the idea of making do without nuclear power (非核家園 - feihe jiayuan) championed by anti-nuclear organisations and the opposition Democratic Progressive Party (DPP). ${ }^{(1)}$ His argumentation seems at times weak but is nevertheless interesting, as it touches on most of the points made and figures cited by Taipower and by President Ma Ying-jeou's government and his Atomic Energy Commission (行政院原子能委員會 - xingzhengyuan yuanzi neng weiyuanhui) in defence of what they deem the overriding need for nuclear energy. Zhang says at the outset that development of the nuclear sector is part of a global trend based on the fact that it is a high-quality energy source that is safe, stable, and clean. He says: "Until now, apart from some doubts over safety, all the other major aspects remain 'unshakeable as a rock'." Other energy sources appear grossly lacking by comparison: Coal is so polluting that the Taiwanese would not tolerate it, and moreover, it has to be imported. The oil used in thermal stations has similarly become a luxury (奢侈品 - shechi pin). Citing unnamed "experts," Zhang says the cost of producing electricity became unviable when oil hit US\$50 a barrel, and today it stands at over US\$100 and could well hit US\$200 given the instability in Libya and several other countries. He says further that there is an "undeniable positive correlation" (絕對的正面關係 - juedui de zhengmian guanxi) between nuclear energy use and economic growth, and that in Taiwan's case, abandoning it would mean the end of the development model that yielded the fruits of prosperity to the Taiwanese. He pours scorn on the benefits of a return to a simple life in harmony with nature, comparing it to what Taiwanese tourists experience in the Indonesian island of Bali.

Certainly, Zhang has a point there. A survey by the polling arm of the TVBS station on 1 April 2011 revealed ambivalence among the Taiwanese on the nuclear issue: 58 percent said Taiwan should gradually give up nuclear energy (23 percent said it was not a necessity), with 51 percent saying they were ready to back such a move even if it meant higher electricity prices (38 percent would then be opposed). At the same time, if closure of nuclear stations means electricity shortages and a negative influence on economic development, just 38 percent of those polled would back the move, with 50 percent opposed. In general, Taiwan's pro-nuclear camp relies on economic arguments, raising the spectre of a steep rise in the cost of living, a drop in Taiwanese firms' international competitiveness, and recession. In response to a Taiwanese lawmaker's move to set a target for ending nuclear energy use, Taipower said it would bring about the country's collapse (整個國家會 跨掉 - zhenggue guojia hui kuadiao). The Ministry of Economic Affairs said such a move would affect electricity consumption by 30 percent of Taiwanese industries. The positions of these two official are contested as unfounded by an editorial in Ziyou Shibao. The editorial says that contrary to the government's stand, the nuclear stations could be closed without plunging Taiwan into a power shortage. It cites three reasons. First, nuclear energy's share remains quite low and can easily be made up for by recourse to other sources, especially through the development of renewable energy and cogeneration. Second, thanks to the massive relocation of energy-hungry industries to mainland China, Taiwan's power generation capacity in fact exceeds demand by 10 percent, meaning that shutting the nuclear plants would have no impact over the next five years. Finally, the only real risk of shortage is in the greater Taipei region, which guzzles a major share of power generated in the south of the island and where consumption due to air-conditioning in the hot season can be reduced by adjusting people's habits and appealing to their conscience.

Apart from economic arguments, opponents of nuclear power in Taiwan cite others that have little to do with consequences for material well1. In April, during the DPP primaries to pick a candidate for the January 2012 presidential election, Tsai
Ing-wen, who emerged successful, said she favoured abandoning nuclear energy by 2025. 
being. They point to risks they consider to be of an altogether different order, with a bearing on the very survival of Taiwan and its population as a whole.

Formosa Weekly's series of articles opens with the gist (p. 4 and 5) of a 15 March 2011 press conference initiated by former Taiwanese vice-president Annette Lu Hsiu-lien to discuss the risks to which nuclear plants are exposed. Among experts present, Lee Chyi-Tyi (李錫堤), professor of applied geology at National Central University, expressed more concern for the safety of plant no. 3 (核三廠 - hesan chang), on the island's south, than for the other two built on the northern coast some 30 kilometres from Taipei. (2) He said that although both these plants sit on a seismic fault, as the Taiwanese media never cease to point out, (3) the fault generates a strong earthquake just once every 700 years. There is thus little likelihood of a major quake in the decades to come. Moreover, only a 600 kilometre to 1,000 kilometre fault can generate sufficient energy for an earthquake of the magnitude that struck Japan. There is no such fault near Taiwan's northern coast. On the other hand, the Manila trench extending from the west of the Philippines to the south of Taiwan can yield an earthquake of magnitude 8.5 and a tsunami so high that the nuclear plant there would not escape unscathed. These conclusions have been confirmed by other researchers, who point out that the possibility of such a quake is all the greater as this trench has not triggered one in 440 years. The wave it would unleash could be five to eight metres high and hit Taiwan's coast (Kenting) in 15 minutes. ${ }^{(4)}$ It would also affect the south-western Chinese coast and threaten four nuclear plants there.

Formosa Weekly likewise focuses on the risks from the nuclear sector's development in China in its article (p. 16) entitled "Threat to Taiwan from Chinese nuclear plants exceeds that from missiles" (中國核電廠對台威脅勝 導彈 - Zhongguo hedianchang dui tai weixie sheng daodan). The article identifies three sources of risk. First, the fact that most Chinese nuclear plants in operation, under construction, or in the planning stage are situated on the coast of three provinces closest to Taiwan - Guangdong, Fujian, and Zhejiang - as pointed out in an accompanying map. Next is the fact that the plants are of the same generation as Fukushima's, that is to say, relatively aged and lacking resistance to tsunamis. Finally, there is the paucity of funds allocated by Beijing toward plant safety. Citing China Daily, the author says Beijing spends on average US\$500,000 a year per plant, whereas in the United States the figure is US\$ 7 million per plant.

The experts writing in Formosa Weekly, however, pointedly voice their concern over the safety and upkeep of Taiwanese plants that have been the focus of heightened worries. Hsu Kuang-jung (徐光蓉), professor of atmospheric sciences (大氣科學 - daqi kexue) at National Taiwan University, says the greatest danger would come from the commissioning of plant no. 4 some 30 kilometres from Taipei, the plans of which were drastically modified by Taipower engineers without prior approval from the various suppliers. Another article (pp. 12 and 13) goes into the details of the four Taiwanese plants' weaknesses, especially those of the fourth. The author asks why, at a time when Germany has decided to close all plants built in the 1980s, Taiwan could not do so for its reactors dating back to the 1970s. He also notes that the fourth plant would not be able to resist an earthquake of more than magnitude 7 . Finally, he cites a report by Taiwan's audit bureau (審計部 - shenji bu) stating that in February 2008, Taipower engineers modified 844 aspects of the plant's plans, including 80 linked to safety measures, and adding that this could entail serious problems.
The Rhythms Monthly article goes over much of the ground covered by others but focuses in particular on the margin of manoeuvrability possible "if Taiwan were to face a nuclear catastrophe." The last section (pp. 69-71) envisages two crisis scenarios in which Taiwan would be faced with high radioactive emissions. The first would stem from a catastrophe on mainland China. A regional map covering the whole of page 68 shows the plants operating in Taiwan, Korea, Japan, and China, highlighting the disquieting proximity of many Chinese plants, especially two located on the Fujian coast (福清核電廠 - fuqing hedianchang and 陽江核電廠 - yangjiang hedianchang). A table citing figures from the World Association of Nuclear Operators and the World Nuclear Association shows that China now has 13 reactors in operation and is counting on 27 more. Given this information, the author says, if one of the plants in provinces close to Taiwan were to emit a radioactive cloud, the island would not escape its effects. The other scenario would be a catastrophe on the Fukushima scale in Taiwan itself. The author stresses that unlike the Japanese, whose country covers an area ten times that of Taiwan, the Taiwanese can count on precious little space to take refuge. With three out of four plants situated on the outskirts of greater Taipei, a crisis leading to an exclusion zone would mean displacing millions of people. The article concludes with a compelling warning: if this possible (萬一 - wanyi) scenario were to come about, Taiwan would not recover.

\section{Translated by N. Jayaram}

2. Usually referred to by numbers 1,2 , and 3, they are called, respectively, Chinshan plant (jinshan chang), Kuosheng plant (guosheng chang), and Maanshan plant (ma'an shan chang).

3. For instance, this banner headline adorned page A2 of Ziyou shibao on 18 March 2011: "Our nuclear plants are situated on a chain of faults." Under it, two maps showed the location of the plants and the faults.

4. Ziyou shibao, 20 April 2011. 